\title{
Late Aragonian mammal sites of Cuesta del Rey (Duero Basin, Burgos, Spain)
}

\author{
Carmen SESÉ* \& Jorge MORALES
}

Museo Nacional de Ciencias Naturales, CSIC. Dpto. Paleobiología. José Gutiérrez Abascal, 2. 28006 - Madrid, Spain; c.sese@mncn.csic.es; mcnm166@mncn.csic.es

* Corresponding author

Sesé, C. \& Morales, J. 2017. Late Aragonian mammal sites of Cuesta del Rey (Duero Basin, Burgos, Spain). [Los yacimientos de mamíferos de Cuesta del Rey del Aragoniense superior (Cuenca del Duero, Burgos, España)]. Spanish Journal of Palaeontology, 32 (1), 63-78.

\section{ABSTRACT}

The Cuesta del Rey mammal sites located on the NE border of the Duero Basin are of great importance with regard to understand the general biostratigraphy of the basin, because Miocene mammal sites are extremely scarce in this area in comparison with the central part of the basin. The mammals identified in Cuesta del Rey-1 are: Eulipotyphla: cf. Miosorex sp.; Rodentia: Heteroxerus sp., Armantomys cf. tricristatus, Megacricetodon ibericus, Megacricetodon minor-Megacricetodon debruijni, Hispanomys sp. and Democricetodon sp. The Cuesta del Rey-1 rodent assemblage is characteristic of the end of the upper Aragonian (MN 7/8, end of the middle Miocene), equivalent to the local subzone $\mathrm{G} 3$ of the $\mathrm{G}$ zone. The presence of the genera Heteroxerus and Armantomys, and the predominance of Megacricetodon (with $80 \%$ of the total percentage of the minimum number of individuals of the micromammals) suggested an open savannah or steppe palaeoenvironment. The mammals identified in Cuesta del Rey-3 are: Rodentia: Megacricetodon cf. ibericus; Artiodactyla: Dorcatherium sp. and Listriodon cf. splendens. Dorcatherium sp. represents the first appearance of the Tragulidae family in the Duero Basin, suggesting the existence of permanent watercourses.

Keywords: Mammals, middle Miocene, upper Aragonian, Duero Basin, Cuesta del Rey sites.

\section{RESUMEN}

Los yacimientos con mamíferos de Cuesta del Rey, situados en el borde NE de la cuenca del Duero, tienen una gran importancia para el conocimiento general de la biostratigrafía de la cuenca debido a la extrema escasez de yacimientos miocenos con mamíferos en comparación con las partes centrales de la misma. Los mamíferos identificados en Cuesta del Rey-1 son: Eulipotyphla: cf. Miosorex sp.; Rodentia: Heteroxerus sp., Armantomys cf. tricristatus, Megacricetodon ibericus, Megacricetodon minor-Megacricetodon debruijni, Hispanomys sp. y Democricetodon sp. Esta asociación, principalmente por la composición de los roedores, es característica del final del Aragoniense superior (final del Mioceno medio), de la subzona G3 de la zona G, unidades MN 7/8. La presencia de los géneros Heteroxerus, Armantomys, y el predominio de Megacricetodon (que constituye el $80 \%$ del porcentaje total del número mínimo de individuos de los micromamíferos), sugieren un ambiente abierto de tipo sabana o estepa. Los mamíferos identificados en Cuesta del Rey-3 son: Rodentia: Megacricetodon cf. ibericus; Artiodactyla: Listriodon cf. splendens and Dorcatherium sp. El tragúlido Dorcatherium sp. representa la primera aparición de la familia en la cuenca del Duero, y sugiere la existencia de cursos de agua permanentes.

Palabras clave: Mamíferos, Mioceno medio, Aragoniense superior, Cuenca del Duero, Yacimientos de Cuesta del Rey. 


\section{INTRODUCTION}

The Cuesta del Rey mammal sites are located on the NE border of the Duero Basin, close to the city of Burgos. This area is near the western end of the Ebro basin; both zones are connected by the Bureba corridor. Unlike other areas of the Duero Basin, the mammal fossil record here is still quite scarce, and for a long time the only findings of remains have involved two species of mastodons near the village of Castrillo del Val, Burgos (Badillo, 1952; Bergounioux \& Crouzel, 1958; Mazo Pérez, 1977). The site was dated as late Vindobonian (equivalent of the upper Aragonian). During the Geological mapping at 1:50.000 scale (Spanish "Plan Magna") in the 1990's, new fossil mammal sites were found including that of Cuesta del Rey-1, the object of the present research. These new sites have made it possible to accurately determine the age of the Miocene formations in this area (Morales \& Sesé, 1997; Pineda, 1997). Subsequent sampling of the same area performed by Olmo et al. (2008) has shown the existence of other mammal sites, among these a new one in the Cuesta del Rey (CR-3) section, presenting an assemblage of small and large mammals.

\section{GEOLOGICAL SETTING}

The Cuesta del Rey section is located close to the village of Villarmero (Burgos). The fossiliferous levels are situated in a butte known as Cuesta del Rey (Fig. 1), which is aligned with two other partially eroded buttes between the Ubierno and Villatoro rivers. The base of the Cuesta del Rey Butte rises along the NW slope from an altitude of $894 \mathrm{~m}$ above sea-level; the outcrop sediments are mudstone, marls and gypsum, attributed to the Villatoro facies (Pineda, 1997). Olmo et al. (2008) suggest that these facies are the lateral continuation of the base of the Riocerezo Series "Marls, silts and terminal limestones" of the Dueñas facies. The Riocerezo rodent site located at the bottom of this series, with Megacricetodon cf. crusafonti and Megacricetodon cf. lopezae, enables these sediments to be dated as upper Aragonian (MN 6) (Olmo et al., 2008). The Cuesta del Rey-3 site is situated at an altitude of 910 $\mathrm{m}$, approximately $10 \mathrm{~m}$ above the contact with the Villatoro facies; the presence of the cricetid Megacricetodon cf. ibericus enabled Olmo et al. (2008) to date the site as upper Aragonian (MN 6/7), suggesting a correlation with the lower part of the Cuesta facies of the central sector of the Duero Basin, in particular with the "Intercalación Ocre". The Cuesta del Rey-1 site, at an altitude of 930 $\mathrm{m}$, approximately $20 \mathrm{~m}$ above Cuesta del Rey-3, is located in terrigenous sediments: yellow and ochre sand, silts and clays. The age of the rodent assemblage was attributed by Morales \& Sesé (1997) to the end of the upper Aragonian (MN 7/8). Pineda (1997) place the site in the Tierra de Campos facies, which is characterized by terrigenous sediments overlying the Villatoro facies, but in nearby areas the terrigenous sediments overlap the terminal limestones of the Dueñas facies. There is therefore an important discrepancy between the work of Pineda (1997) and Olmo et al. (2008) in relation to the interpretation of the sedimentary facies in this area. However, the discrepancy is not due to erroneous dating of the sites, as stated by Olmo et al. (2008), but rather to different interpretations of the relationships between the facies supported by the new biostratigraphic data.

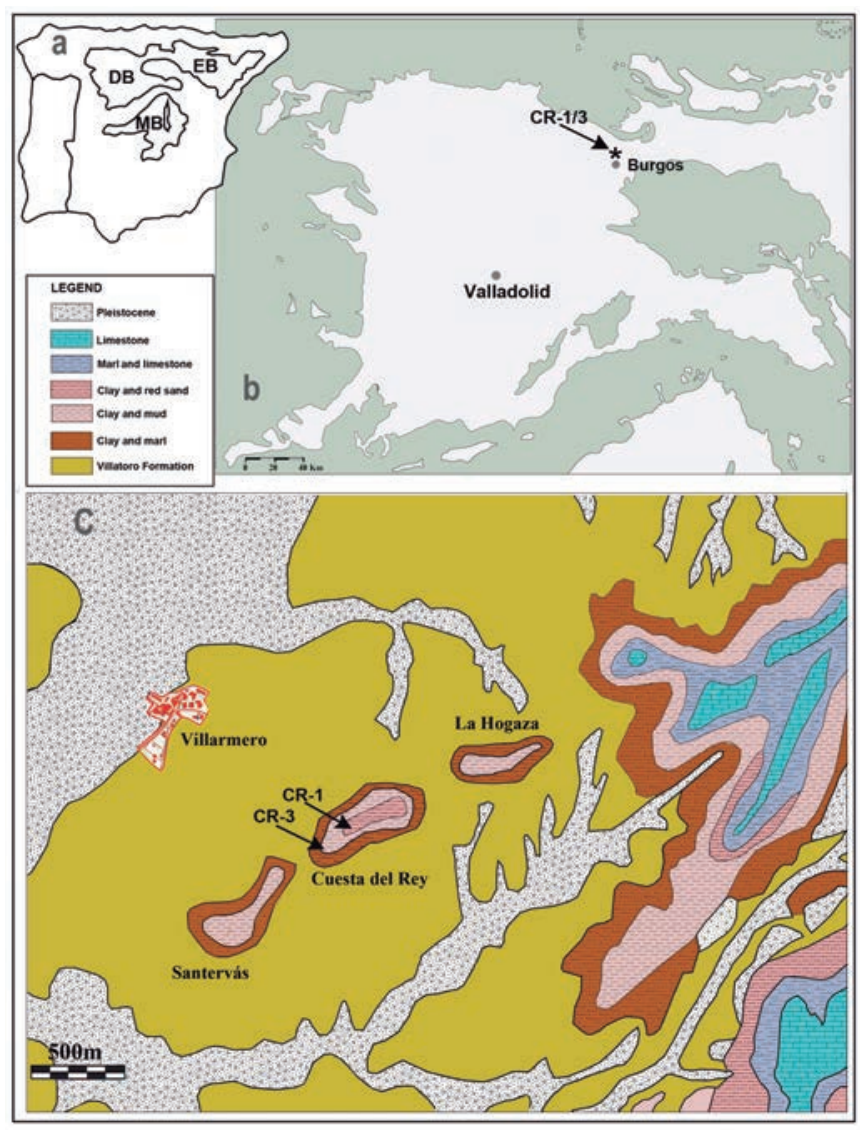

Figure 1. a) Location map of the Duero Basin (DE), Ebro Basin (EB) and Madrid Basin (MB) in the Iberian Peninsula. b) Location map of Cuesta del Rey mammal localities (CR-1 and CR-3) in the Cenozoic Duero Basin. c) The geological scheme of Cuesta del Rey area is based on the MAGNA geological map of Burgos -Sheet 200(Pineda, 1977). 


\section{METHODOLOGY}

In Cuesta del Rey-1, $150 \mathrm{~kg}$ of sediment were screenwashed with different mesh sizes, the smallest of which was $0.5 \mathrm{~mm}$. The fossils were selected with the use a stereomicroscope. Among the fossiliferous remains 140 identifiable teeth of micromammals were found. The material from Cuesta del Rey-1/3 is stored in the collections of the MNCN.

The teeth were measured with a Nikon Measuroscope $105 \mathrm{x}$ microscope with an incorporated micrometer of an accuracy of $0.025 \mathrm{~mm}$. The measurements are maximum length (L) and width (W) of the occlusal surface of the tooth, and have been taking after Reumer (1984) for Soricidae, Cuenca Bescós (1988) for Sciuridae, García Paredes (2006) for Gliridae, and Daams \& Freudenthal (1988) for Cricetidae; we give the maximum (Max.), medium (Med.) and minimum (Min.) in millimeters (mm) for the number of teeth measured $(\mathrm{N})$.

The teeth were drawn with a Nikon SMZ-10 40x microscope with an attached light camera, and the drawings were redrawn with the Corel Drawn software.

The photographs of the micromammal teeth were taken at the Laboratory of Optical Microscopy of the Museo Nacional de Ciencias Naturales (MNCN) with the use of the FEI Quanta 200 Scanning Electronic Microscope (SEM) in mode Low Vacuum.

The nomenclature used for the teeth of the different groups of micromammals follows Sesé (1980).

To compare the relative abundance of the different micromammals, we employed the Minimal Number of Individuals (MNI) of each taxon using the most abundant piece, taking into account the highest number between lefts and rights.

\section{SYSTEMATIC PALAEONTOLOGY}

Class MAMMALIA Linnaeus, 1758

Order EULIPOTYPHLA Waddell, Okada \& Hasegawa, 1999

Family Soricidae Fischer, 1814

Genus Miosorex Kretzoi, 1959

cf. Miosorex sp.

(Figs 2a, 3a)

Locality. Cuesta del Rey-1.

Material and measurements. $1 \mathrm{~m} 3: \mathrm{L}=1.06 \mathrm{~mm}$; $\mathrm{W}=0.68 \mathrm{~mm}$.

Description and discussion. The size of this molar fits within the variability of that of Miosorex grivensis, and
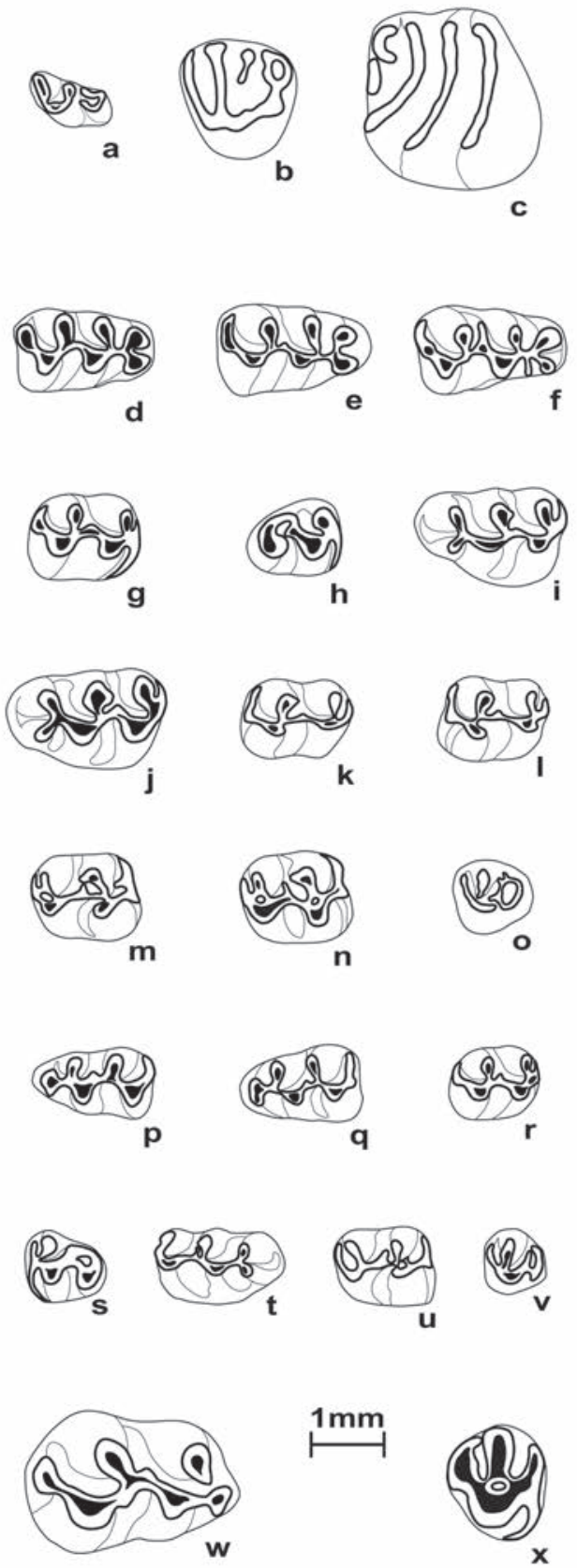

Figure 2. Drawings of the micromammal tooth in occlusal view from Cuesta del Rey-1. (a) cf. Miosorex sp., left m3 (CR-1: s/n 4). (b) Heteroxerus sp., left P4 (CR-1: s/n: 8). (c) Armantomys cf. tricristatus, left $\mathrm{m} 2$ (CR-1: $\mathrm{s} / \mathrm{n}$ : 1); (d-o) Megacricetodon ibericus, d) right $\mathrm{m} 1$ (CR1: 9); e) right $\mathrm{m} 1$ (CR-1: 2); f) right $\mathrm{m} 1$ (CR-1: 3); g) right $\mathrm{m} 2$ (CR-1: 39); h) right $\mathrm{m} 3$ (CR-1: $\mathrm{s} / \mathrm{n}: 8)$; i) left M1 (CR-1: 103); j) left M1 (CR-1: 102); k) left M2 (CR-1: 79); l) left M2 (CR-1: 88); m) right M2 (CR-1: 89); n) right M2 (CR-1: 82); o) left M3 (CR1: 100). (p-v) Megacricetodon minor-Megacricetodon debruijni: p) left $\mathrm{m} 1$ (CR-1: 17); q) left $\mathrm{m} 1$ (CR-1: 18); r) right $\mathrm{m} 2$ (CR-1: 37); s) left $\mathrm{m} 3$ (CR-1: $\mathrm{s} / \mathrm{n}$ : 17); t) right $\mathrm{M} 1$ (CR-1: 114); u) right $\mathrm{M} 2$ (CR-1: 93); v) left M3 (CR-1: 98); (w) Hispanomys sp., right m1 (CR-1: s/n: 1); (x) Democricetodon sp., right M3 (CR-1: s/n: 3). 
its morphology, with the talonid basin greatly reduced, is characteristic of this species (Sesé, 1980). Sesé (1980) defined the new subspecies of Miosorex grivensis lopezae Sesé 1980 at the Escobosa de Calatañazor site, based on some dental and mandibular characters that distinguish it from the subspecies Miosorex grivensis grivensis of the type-site of La Grive de Saint Alban, where the species was defined. Nonetheless, the material from Cuesta del Rey1 is so scarce that we reservedly determine the Soricidae from this site as cf. Miosorex sp.

Order RODENTIA Bowdich, 1821

Family Sciuridae Fischer de Waldheim, 1817

Genus Heteroxerus Stehlin \& Schaub, 1951

\section{Heteroxerus sp.}

(Figs 2b, 3b)

Locality. Cuesta del Rey-1.

Material and measurements. $1 \mathrm{P} 4: \mathrm{L}=1.47 \mathrm{~mm}$; $\mathrm{W}=$ $1.56 \mathrm{~mm}$.

Description and discussion. The morphology of this tooth is characteristic of the genus Heteroxerus. Its size is greater than or close to the maximum values of the different populations of Heteroxerus rubricati Crusafont, Villalta \& Truyols, 1955. It is somewhat smaller or close to the minimum values of Heteroxerus grivensis (Forsyth Major, 1893), mainly in relation to length (Cuenca Bescós, 1988), and is also smaller than the values of the population of the latter species from Escobosa de Calatañazor (Sesé, 1980). As this tooth exhibits no characters to distinguish between both species, and its size is not differential, because it fits within the variability of both species, it cannot be assigned to either of them.

Family Gliridae Muirhead, 1819

Genus Armantomys de Bruijn, 1966

Armantomys cf. tricristatus López Martínez, 1977, in: López Martínez, Sesé Benito \& Sanz García, 1977

(Figs 2c, 3c-d)

Locality. Cuesta del Rey-1.

Material and measurements. $1 \mathrm{~m} 2: \mathrm{L}=2.24 \mathrm{~mm} ; \mathrm{W}=$ $2.16 \mathrm{~mm} ; 1 \mathrm{P} 4: \mathrm{L}=1.0 \mathrm{~mm} ; \mathrm{W}=1.49 \mathrm{~mm}$.

\section{Description.}

m2. In the $\mathrm{m} 2$ of Cuesta del Rey-1, the ridge curvature is greater than that of Armantomys aragonensis de Bruijn, 1966, and is similar to that of Armantomys tricristatus. The anterolophid is shorter than in Armantomys aragonensis and similar to that of Armantomys tricristatus. These two characters enable both species to be distinguished (López Martínez et al., 1977; Daams, 1990). The size of the m2 is bigger than that of Armantomys aragonensis (Bruijn 1966, 1967; Daams, 1990; García Paredes, 2006), and fits within the variability of Armantomys tricristatus (López Martínez et al., 1977; Sesé, 1980; Daams, 1990; García Paredes, 2006).

P4. In the P4 of Cuesta del Rey-1, there is no anterocone or anteroloph, as occurs in Armantomys tricristatus, a character that allows it to be distinguished from that of Armantomys aragonensis, which generally presents an anterocone (Daams, 1990; García Paredes, 2006). The size of the P4 is more similar to that of Armantomys aragonensis, although García Paredes (2006) points out that there are no notable differences in the size of this tooth between both species.

Discussion. Although the material from Cuesta del Rey-1 fits well in Armantomys tricristatus, its size and morphology are less evolved than those of the population of Escobosa de Calatañazor, the site where the species was described (López Martínez et al., 1977; Sesé, 1980), in which the curvature of the ridges is even more marked than in the material of Cuesta del Rey-1. Daams (1990) considers $A$. aragonensis - A. tricristatus to constitute a different lineage, bigger than that of the small-to-medium size of A. bijmai (Lacomba \& Martínez Salanova, 1988) A. daamsi (de Visser, 1990, in: Álvarez Sierra et al., 1990a) - A. parsani Daams, 1990- A. jasperi Daams, 1990. The $A$. aragonensis - $A$. tricristatus lineage is characterized by a tendency towards increased molar size, greater inclination of the ridges, shortening of the anteroloph in the lower molars and the loss of the anterocone in the P4 (Daams, 1990). Based upon all these data, and due to the scarcity of the material in Cuesta del Rey-1, we reservedly identify it as Armantomys cf. tricristatus.

Family Cricetidae Fischer de Waldheim, 1817

Genus Megacricetodon Fahlbusch, 1964

Megacricetodon ibericus (Schaub, 1944)

(Figs 2d-o, 3e-r)

Locality. Cuesta del Rey-1.

Material. $32 \mathrm{~m} 1 ; 31 \mathrm{~m} 2 ; 9$ m3; $15 \mathrm{M} 1 ; 21 \mathrm{M} 2 ; 4 \mathrm{M} 3$.

Measurements. See Table 1.

Description. For the morphological description of the molars we follow the morphotypes distinguished by Daams \& Freudenthal (1988) for the lineage Megacricetodon primitivus (Freudenthal, 1963) - Megacricetodon collongensis (Mein, 1958) - Megacricetodon collongensiscrusafonti-Megacricetodon crusafonti (Freudenthal, 1963) 
- Megacricetodon crusafonti-ibericus - Megacricetodon ibericus. Oliver Pérez (2015) recently reviewed this lineage, of which she retains the lineage of Megacricetodon crusafonti - Megacricetodon crusafonti-ibericus Megacricetodon ibericus, which due to its morphology is the most interesting one with regard to the taxonomic determination of the material of Cuesta del Rey-1.

$\mathbf{m 1}$. There are four morphotypes for the anteroconid in the genus Megacricetodon, from rounded or bean-shaped (first morphotype) to deeply split, forming an X pattern with the protoconid and metaconid (fourth morphotype). In Cuesta del Rey-1 the latter morphotype is the only one present, at least in the 23 specimens presenting no wear that could affect the morphology, as occurs in Megacricetodon ibericus. One specimen (Fig. 2f) presents a long labial spur of the anterolophid, a character that was pointed out by Daams \& Freudenthal (1988) in a few specimens of $M$. primitivus and $M$. collongensis.

In the genus Megacricetodon the mesolophid presents four morphotypes from long to absent. In Cuesta del Rey1, its variation is the following: of the 29 specimens in which this character is observable, only $3(10 \%)$ exhibit a medium-sized mesolophid (second morphotype), 16 (55\%) present a short mesolophid developed as a small protuberance of the ectolophid (third morphotype), and $10(35 \%)$ have no mesolophid (fourth morphotype). In the Megacricetodon crusafonti - Megacricetodon ibericus lineage, there is a trend towards the reduction of the mesolophid, which practically disappears in the latter species, as occurs in the material of Cuesta del Rey-1 where it is generally absent.

m2. There are three morphotypes for the lingual anterolophid of the genus Megacricetodon, from long and well developed to absent. Of the 26 specimens of Cuesta del Rey-1 in which this character is observable, $6(23 \%)$ display a short or weakly defined lingual anterolophid (second morphotype), and 20 (77\%), most of the population, present no lingual anterolophid at all (third morphotype). In the Megacricetodon crusafonti Megacricetodon ibericus lineage, the lingual anterolophid tends become reduced. In Megacricetodon ibericus the third morphotype is the most abundant one, the second

Table 1. Measurements of the molars of Megacricetodon ibericus from Cuesta del Rey-1.

\begin{tabular}{|l|r|l|l|l|r|l|l|l|}
\hline \multirow{2}{*}{ MOLAR } & \multirow{2}{*}{$\mathrm{N}$} & \multicolumn{3}{|c|}{ LENGTH in mm } & \multirow{2}{*}{$\mathrm{N}$} & \multicolumn{3}{|c|}{ WITH in mm } \\
\cline { 3 - 5 } \cline { 7 - 9 } & & Min. & Med. & Max. & & Min. & Med. & Max. \\
\hline m1 & 19 & 1.63 & 1.72 & 1.82 & 19 & 0.97 & 1.05 & 1.12 \\
\hline m2 & 21 & 1.21 & 1.30 & 1.42 & 22 & 0.90 & 1.07 & 1.16 \\
\hline m3 & 9 & 1.01 & 1.11 & 1.23 & 9 & 0.80 & 0.90 & 0.98 \\
\hline M1 & 14 & 1.67 & 1.79 & 1.93 & 14 & 1.04 & 1.14 & 1.23 \\
\hline M2 & 18 & 1.26 & 1.33 & 1.40 & 19 & 0.98 & 1.08 & 1.16 \\
\hline M3 & 4 & 0.83 & 0.88 & 0.94 & 4 & 0.81 & 0.88 & 0.93 \\
\hline
\end{tabular}

morphotype is present in a few specimens, and none of them exhibit the first one, as occurs in the Cuesta del Rey1 population.

In the genus Megacricetodon the mesolophid presents four morphotypes from long to absent. In Cuesta del Rey-1, its variation is the following: of 31 specimens, $9(29 \%)$ have a short mesolophid developed as a small protuberance of the ectolophid (third morphotype), and 22 (71\%) have no mesolophid (fourth morphotype). In the Megacricetodon crusafonti - Megacricetodon ibericus lineage, the mesolophid shows a tendency to become reduced, totally disappearing in the latter species as occurs with most of the Cuesta del Rey-1 material.

M1. The anterocone presents four morphotypes in the genus Megacricetodon, from a simple cusp (very scarce even in primitive species such as Megacricetodon primitivus and Megacricetodon collongensis) to deeply split and with a small cingulum ridge at its anterior edge in front of the anterocone (fourth morphotype). The latter morphotype is the only one in Megacricetodon ibericus, as occurs in the whole Cuesta del Rey-1 population.

With respect to the development of the labial spur on the anterolophule, of the three morphotypes distinguished in the genus Megacricetodon (from well-developed to absent) none exist in the Cuesta del Rey-1 specimens, as occurs in Megacricetodon ibericus.

In relation to the three morphotypes of the development of the paracone ectoloph, from absent (first morphotype) to well developed (third morphotype), the 15 specimens of Cuesta del Rey-1 present a short ectoloph (second morphotype), a similar development to what occurs in Megacricetodon ibericus.

The mesoloph presents four morphotypes in the genus Megacricetodon, from long to absent. The variation of the 15 Cuesta del Rey-1 specimens is the following: in the vast majority (12 specimens; $80 \%$ ) it does not exist (fourth morphotype), and only 3 specimens (20\%) develop a very short mesoloph, as a small protuberance of the entoloph (third morphotype), as occurs in Megacricetodon ibericus.

The posterosinus displays four morphotypes in the genus Megacricetodon, from well developed to absent. Its variation in the 15 Cuesta del Rey-1 specimens is the following: in the vast majority (12 specimens; $80 \%$ ), the posteroloph is very short and encloses a small posterosinus (third morphotype), and in 3 specimens $(20 \%)$ no posteroloph or posterosinus exist, as occurs in Megacricetodon ibericus.

M2. The protolophule variation presents five morphotypes in the genus Megacricetodon. In the 20 Cuesta del Rey-1 specimens, its variation is the following: in 7 specimens $(35 \%)$ the protolophule is transverse to the protocone (second morphotype), in 3 (15\%) the protolophule is transverse to the entoloph behind the protocone (third morphotype), in 7 (35\%) the protolophule connects with the entoloph and the sinus is strongly curved 


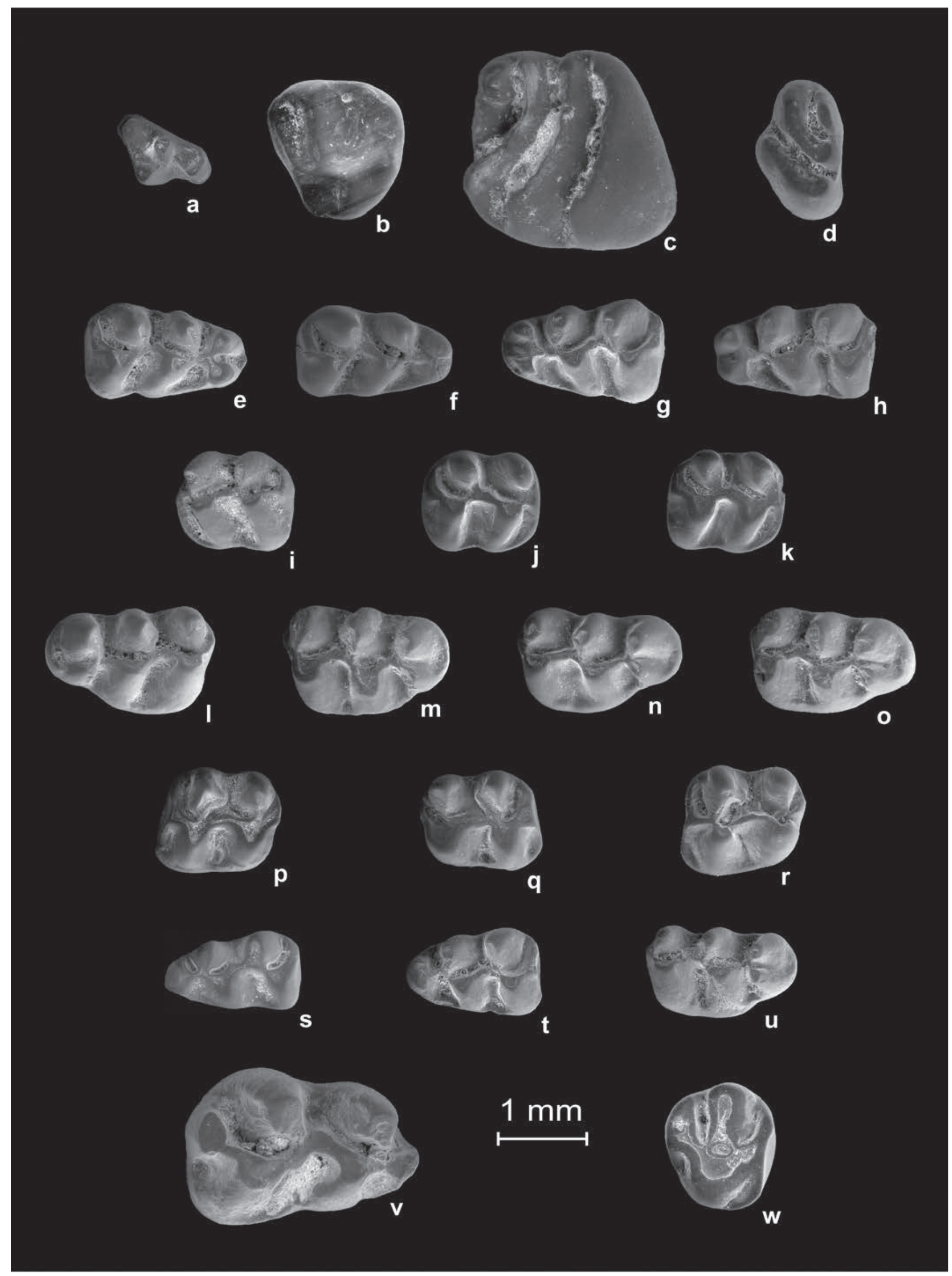


forward (fourth morphotype), and in 3 (15\%) there is a double protolophule (fifth morphotype). This development is similar to what occurs in Megacricetodon ibericus.

As it happens in the $\mathrm{M} 1$, in relation to the three morphotypes presented by the development of the ectoloph of the paracone in the genus Megacricetodon, from absent (first morphotype) to well developed (third morphotype), the 21 Cuesta del Rey-1 specimens exhibit a short ectoloph (second morphotype).

In the Cuesta del Rey-1 population, the representation of the three morphotypes of the sinus in the genus Megacricetodon is the following: in 3 specimens (14\%) the sinus is transverse (first morphotype), in $9(43 \%)$ the sinus is slightly curved forward (second morphotype), and in the other $9(43 \%)$ it is strongly curved forward (third morphotype). The latter two morphotypes, the most frequent ones in the Cuesta del Rey-1 population, are also the most frequent in Megacricetodon crusafonti and Megacricetodon ibericus.

Discussion. The population of Cuesta del Rey-1 presents the characteristics of Megacricetodon ibericus according to Daams \& Freudenthal (1988): m1 with a deeply split anteroconid and a greatly reduced or absent mesolophid; $\mathrm{m} 2$ with a very reduced lingual anterolophid, which is generally absent, and a greatly reduced mesolophid which in most of the population does not exist and in the rest is very short and developed as a small protuberance of the ectolophid; M1 with the anterocone deeply split and with a small cingulum at its anterior border, absence of a labial spur on the anterolophule, ectoloph of the paracone always present, mesoloph absent in the vast majority and very reduced in the rest, developed as a small protuberance of the entoloph, and a greatly reduced or absent posteroloph and posterosinus; M2 with the protolophule generally connected to the protocone and to the entoloph, ectoloph of the paracone always present, and the sinus curved forward in the majority of the specimens. The morphology and size of the material from Cuesta del Rey-1 are similar to those of the populations of Megacricetodon ibericus from several sites in the Calatayud-Teruel basin (Daams \& Freudenthal, 1988; Oliver Pérez, 2015) and of the Escobosa de Calatañazor site in the Duero Basin (Sesé, 1977, 1980).
Megacricetodon minor (Lartet, 1851) - Megacricetodon debruijni Freudenthal, 1968

(Figs 2p-v, 3s-u)

Locality. Cuesta del Rey-1.

Material. $2 \mathrm{~m} 1 ; 3 \mathrm{~m} 2 ; 4 \mathrm{~m} 3 ; 2 \mathrm{M} 1 ; 2 \mathrm{M} 2 ; 2 \mathrm{M} 3$.

Measurements. See Table 2.

Table 2. Measurements of the molars of Megacricetodon minorMegacricetodon debruijni from Cuesta del Rey-1.

\begin{tabular}{|l|c|c|}
\hline MOLAR & L in $\mathrm{mm}$ & W in mm \\
\hline m1 (CR-1: 17) & 1.47 & 0.86 \\
\hline m1 (CR-1: 18) & 1.44 & 0.95 \\
\hline m2 (CR-1: 36) & 1.05 & 0.86 \\
\hline m2 (CR-1: 37) & 1.05 & 0.85 \\
\hline m2 (CR-1: 60) & 1.10 & 0.96 \\
\hline m3 (CR-1: s/n: 7) & 0.95 & 0.79 \\
\hline m3 (CR-1: s/n: 13) & 0.95 & 0.81 \\
\hline m3 (CR-1: s/n: 15) & 0.97 & 0.83 \\
\hline m3 (CR-1: s/n: 17) & 1.00 & 0.84 \\
\hline M1 (CR-1: 114) & 1.56 & 0.92 \\
\hline M1 fr. (CR-1: 119) & ---- & ---- \\
\hline M2 (CR-1: 92) & 1.18 & 0.97 \\
\hline M2 (CR-1: 93) & 1.20 & 1.00 \\
\hline M3 (CR-1: 98) & 0.74 & 0.80 \\
\hline M3 (CR-1: 99) & 0.78 & 0.81 \\
\hline
\end{tabular}

Description. The size of this material, especially $\mathrm{m} 1$ and $\mathrm{M} 1$, is generally close to the maximum values of some populations of Megacricetodon minor (Las Planas 5H) and Megacricetodon debruijni (Carrilanga) according to the data of Daams \& Freudenthal (1988).

For morphological description of the material we used the emended diagnosis of Megacricetodon minor

Figure 3. Scanning electronic microscope photographs of the micromammal tooth in occlusal view from Cuesta del Rey-1. (a) cf. Miosorex sp., left m3 (CR-1: s/n: 4). (b) Heteroxerus sp.: left P4 (CR-1: s/n: 8). (c-d) Armantomys cf. tricristatus, c) left $\mathrm{M}_{2}$ (CR-1: s/n: 1); d) left P4 (CR-1: s/n: 2). (e-r) Megacricetodon ibericus, e) right $\mathrm{m} 1$ (CR-1: 4); f) right m1 (CR-1: 6); g) left $\mathrm{m} 1$ (CR-1: 7); h) left $\mathrm{m} 1$ (CR-1: 10); i) left $\mathrm{m} 2$ (CR-1: 44); j) right $\mathrm{m} 2$ (CR-1: 52); k) right $\mathrm{m} 2$ (CR-1: 42); l) left M1 (CR-1: 105); m) right M1 (CR-1: 108); n) right M1 (CR-1: 110); o) right M1 (CR-1: 112); p) left M2 (CR-1: 72); q) right M2 (CR-1: 75); r) left M2 (CR-1: 81). (s-u) Megacricetodon minor-Megacricetodon debruijni, s) left m1 (CR-1: 17); t) left m1 (CR-1-18); u) right M1 (CR-1: 114). (v) Hispanomys sp., right m1 (CR-1). (w) Democricetodon sp., right M3 (CR-1). 
and Megacricetodon debruijni performed by Daams \& Freudenthal (1988).

m1. One of the two specimens has a simple anteroconid as occurs in Megacricetodon minor, and the other one presents a slightly subdivided anteroconid as in Megacricetodon debruijni, although in the latter species the anteroconid is divided into two separated cusps by a deep split, according to Daams \& Freudenthal (1988). The mesolophid is very reduced and barely outlined, as occurs in Megacricetodon debruijni, where it is short or absent, whereas in Megacricetodon minor it is generally well developed (long, medium length or short).

m2. The mesolophid is very reduced: it is absent in 2 of 3 specimens and in another one it is barely outlined.

M1. The anterocone is completely divided, as occurs in Megacricetodon debruijni and in $70 \%$ of Megacricetodon minor according to Daams \& Freudenthal (1988). They display a short mesoloph and a simple protolophule.

M2. One of the two specimens presents a short mesoloph, which is absent in the other. In one of the two specimens, there is a simple metalophule and in the other, this is double. In one specimen, the sinus is transverse (the most frequent morphotype in Megacricetodon minor), whilst in the other it is strongly curved forwards, as occurs in Megacricetodon debruijni.

Discussion. The principal character enabling Megacricetodon minor and Megacricetodon debruijni to be distinguished involves the presence of a simple $\mathrm{m} 1$ anteroconid in the former species, and a divided anteroconid in the latter one, according to Freudenthal (1968). In one of the two $\mathrm{m} 1$ of Cuesta del Rey-1 the anteroconid is simple, as in Megacricetodon minor and in the other specimen the anteroconid is subdivided, although in Megacricetodon debruijni the anteroconid is completely divided into two cusps. The reduction of the mesolophids in $\mathrm{m} 1$ and $\mathrm{m} 2$ and mesolophs in M1 and M2 from Cuesta del Rey-1 is similar to what occurs in Megacricetodon debruijni.

The material from Cuesta del Rey-1 is very scarce and shows, as has previously been stated, some characters of Megacricetodon minor, on the one hand, and of Megacricetodon debruijni on the other. For this reason we denominate the material of this site Megacricetodon minor-Megacricetodon debruijni, in a similar way as in the Escobosa de Calatañazor site, where it constitutes a transitional form of both species (Sesé, 1980).

Genus Hispanomys (Mein \& Freudenthal, 1971)

\section{Hispanomys sp.}

(Figs 2w, 3v)

Locality. Cuesta del Rey-1.
Material and measurements. $1 \mathrm{ml}: \mathrm{L}=2.51 \mathrm{~mm} ; \mathrm{W}=$ $1.74 \mathrm{~mm} ; 1$ fr. M2.

\section{Description.}

m1. The anterior metalophulid is interrupted, and the metaconid therefore remains as an independent cusp disconnected from the anteroconid. The anteroconid does not display a cingular ridge. The mesolophid is very short and barely outlined.

M2. Only the anterior part of the tooth is preserved, which reveals that the ectoloph of the paracone is short and incomplete.

Discussion. The measurements of this material fit within the variability of the size of Cricetodon jotae (Mein \& Freudenthal, 1971) from Manchones (Freudenthal, 1963, 1966) and Hispanomys aguirrei (Sesé 1977, in: López Martínez et al., 1977) from Escobosa de Calatañazor (López Martínez et al., 1977; Sesé, 1980) and Nombrevilla-2 (López Guerrero et al., 2008). Due to the great morphological variability of these species and to the scarce material from Cuesta del Rey-1, it cannot be assigned to either of them. Nonetheless, it presents the advanced characters that are most frequent in the genus Hispanomys in general and in the species Hispanomys aguirrei in particular: anterior metalophulid in $\mathrm{m} 1$ (interrupted in Cuesta del Rey-1) and a developed but incomplete ectoloph in M2.

Genus Democricetodon Fahlbusch, 1964

Democricetodon sp.

(Figs 2x, 3w)

Locality. Cuesta del Rey-1.

Material and measurements. $1 \mathrm{M} 3: \mathrm{L}=1.25 \mathrm{~mm}$; $\mathrm{W}=1.38 \mathrm{~mm}$.

Description and discussion. This specimen exhibits the characteristic morphology and size of the genus Democricetodon. It presents a very simplified morphology, which is similar to morphotype D (mesoloph absent) of the genus Democricetodon according to Freudenthal \& Daams (1988; Fig. 2D, p. 139), and is also similar to morphotype $\mathrm{S}$ (centroloph connecting the hypocone with the postero-labial border of the molar) of Freudenthal \& Daams (1988; Fig. 1s, p. 136). Its relatively large size fits with the variability of that of Democricetodon freudenthali (Antunes \& Mein, 1981) and Democricetodon darocensis (Freudenthal, 1963) according to the data of Freudenthal \& Daams (1988), and it is a smaller than the populations of Democricetodon crusafonti (Agustí, 1978) from Escobosa de Calatañazor (Sesé, 1980) and of the Calatayud-Teruel Basin (Meulen et al., 2003). However, as there is only 

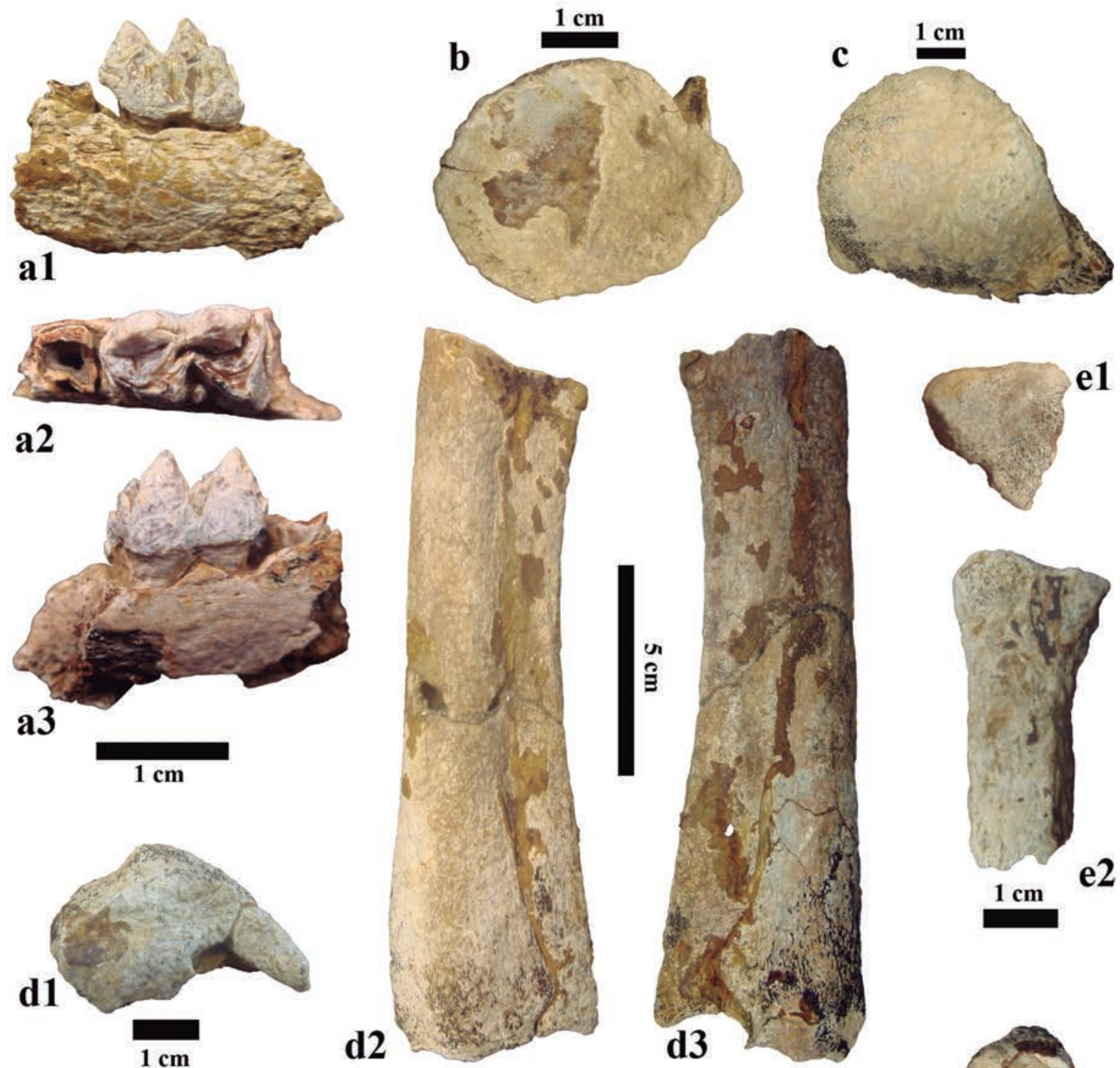

\section{d2}
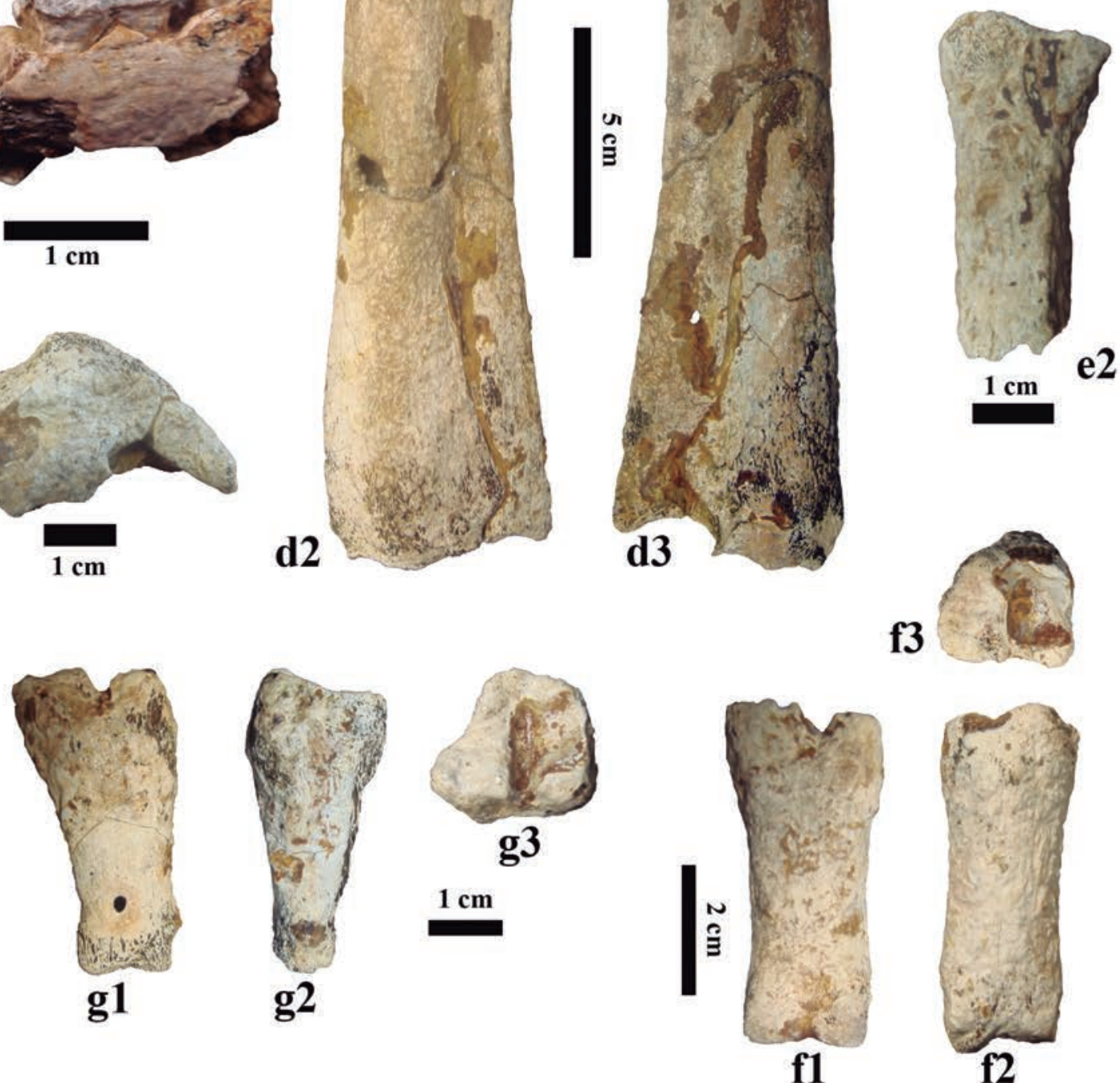

f3
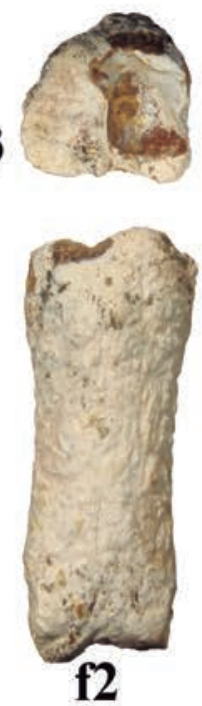

Figure 4. Large mammals from Cuesta del Rey-3. (a) Dorcatherium sp. CR-3-7, left fragment of mandible with m1; a1) buccal view, a2) occlusal view, a3) lingual view. (b-g) Listriodon cf. splendens; b) CR-3-1, left proximal epiphysis of scapula (glenoid cavity) in proximal view. c) CR-3-2, left proximal humerus epiphysis in proximal view. d) CR-3-3, left distal epiphysis of radius-ulna; d1) dorsal view, d2) palmar view, d3) distal view. e) CR-3-4, left proximal central metacarpal; e1) proximal view, e2) lateral view. f) CR-3-5, left first central phalanx; f1) palmar view, f2) dorsal view, f3) proximal view. g) CR-3-6, left first central phalanx; g1) palmar view, g2) lateral view, g3) proximal view. 
one non-diagnostic tooth, which displays a highly variable morphology, it cannot be assigned taxonomically to any species.

Table 3. Measurements in $\mathrm{mm}$ of the postcranial bones of Listriodon cf. splendens from Cuesta del Rey-3. L. P-D = Length proximal-distal; L.L-M PE = Length lateral-medial proximal epiphysis; L.D-P PE = Length dorsal-palmar proximal epiphysis; L.L-M DE = Length lateral-medial distal epiphysis; L.D-P DE = Length dorsal-palmar DE epiphysis.

\begin{tabular}{|c|c|c|c|c|c|}
\hline & Scapula & Radius/Ulna & Metacarpal & Phalanx I & Phalanx I \\
\hline L.P-D & & & & 48.8. & \\
\hline L.L-M PE & 33 & & 20.9 & 21.4 & 22 \\
\hline L.D-P PE & 45 & & 21.5 & 21 & 20 \\
\hline L.L-M DE & & 48 & & 18 & \\
\hline L.D-P DE & & 38 & & 15 & \\
\hline
\end{tabular}

Order ARTIODACTYLA Owen, 1848

Familily Suidae Gray, 1821

Genus Listriodon von Meyer, 1846

Listriodon cf. splendens von Meyer 1846 (Figs 4b-g)

Locality. Cuesta del Rey-3.

Material. Left forelimb association; CR-3-1, proximal epiphysis of scapula (glenoid cavity), CR-3-2, proximal epiphysis of humerus, CR-3-3, distal fragment of radius; CR-3-4, proximal fragment of central metacarpal, CR-35, CR-3-6, two phalanx I.

\section{Measurements. Table 3.}

Description and discussion. This fossil assemblage was found on the surface; all bones were eroded, presenting root marks. The size of the two first phalanges is close to the undescribed homologous material from the locality of Toril-3, whose dentition was determined as Listriodon splendens by Pickford \& Morales (2003).

Family Tragulidae Milne-Edwards, 1864

Genus Dorcatherium Kaup \& Scholl, 1834

\section{Dorcatherium sp.}

(Fig. 4a)

Locality. Cuesta del Rey-3.

Material and measurements. CR-3-7, left $\mathrm{m} 1: \mathrm{L}=$ $11.5 \mathrm{~mm} ; \mathrm{W}=7.3 \mathrm{~mm}$.

Description and discussion. The $\mathrm{m} 1$ presents a wellmarked "Dorcatherium fold" and the absence of a stylid in the buccal wall both constitute diagnostic features of
Dorcatherium lower dentition (Morales et al., 2012). The size is close to both $D$. crassum and $D$. naui. Consequently, a more accurate determination is not feasible. Tragulidae species are characteristic of riparian habitats, and this tooth is the oldest record of the family in the Duero Basin.

\section{RESULTS AND DISCUSSION}

In the present paper, the following mammals are identified in the new Cuesta del Rey-1 site: Eulipotyphla: Soricidae: cf. Miosorex sp.; Rodentia: Sciuridae: Heteroxerus sp.; Gliridae: Armantomys cf. tricristatus; Cricetidae: Megacricetodon ibericus, Megacricetodon minorMegacricetodon debruijni, Hispanomys sp. and Democricetodon sp.; the following ones are identified in Cuesta del Rey-3: Artiodactyla: Dorcatherium sp. and Listriodon cf. splendens.

This micromammal assemblage is characteristic of the end of the upper Aragonian (end of the middle Miocene), in subzone G3 of the G zone according to Daams \& Freudenthal (1988), units MN 7/8 of Mein (1975). The species Megacricetodon ibericus appears in this subzone, continuing in zone H of the lower Vallesian (Sesé, 1980; Álvarez Sierra et al., 2003; Dam et al., 2014). The population of Megacricetodon minor-Megacricetodon debruijni from Cuesta del Rey, with a morphology between both species, is similar to the populations of this taxa of some sites of the final of the upper Aragonian (subzone G3), whereas de more evolved species of both, Megacricetodon debruijni, is characteristic of the early Vallesian. The genus Armantomys, a characteristic taxon mainly recorded in the early and middle Miocene of the central basins of the Iberian Peninsula (Duero, Tagus, Calatayud-Teruel, Ebro) and the Levant, but not in the Vallès-Penedès Basin (Sesé, 1988), was last recorded in subzone G3 at the end of the Aragonian (Daams, 1990; Sesé, 2006). Outside Spain Baudelot \& Collier (1982) have cited an unique tooth as Armantomys aragonensis from Liet (Gers, France).

The Cuesta del Rey-1 site can be also situated in the cenozone of Megacricetodon ibericus (Álvarez Sierra et $a l ., 1990 \mathrm{~b}$ ) by the record of this species and its association with Megacricetodon minor-Megacricetodon debruijni. This cenozone also contains the sites from the Duero Basin of La Parrilla, Casasola 2, Torrelobatón-1 and 2, Buenaventura-4 and 5, Torremormojón-5 and Ampudia-10 (Álvarez Sierra et al., 1990b). Cuesta del Rey-1 also has all the taxa in common with Escobosa de Calatañazor, from the Duero Basin, a karstic site from the end of the upper Aragonian (Sesé, 1980), and with other sites from the Duero, Tagus and Daroca-Nombrevilla basins of this age (Fig. 5). 


\begin{tabular}{|c|c|c|c|c|}
\hline 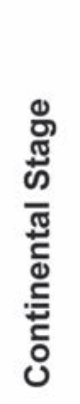 & $\begin{array}{l}\stackrel{0}{\check{0}} \\
\stackrel{N}{\mathbf{Z}} \\
\mathbf{Z}\end{array}$ & 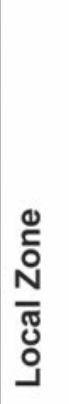 & LOCALITIES & 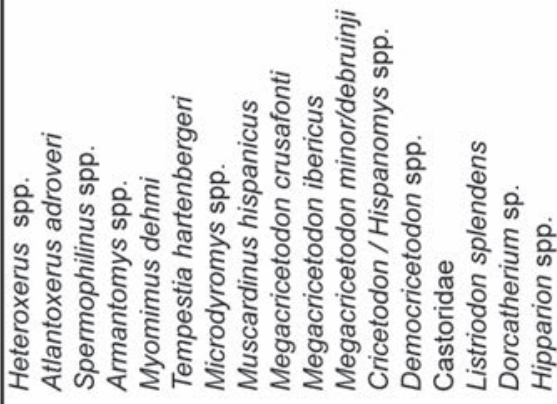 \\
\hline \multirow{6}{*}{ 足先 } & \multirow{6}{*}{9} & \multirow{7}{*}{$\begin{array}{l}1 \\
H\end{array}$} & \multirow{7}{*}{$\begin{array}{l}\text { Los Valles de F. } \\
\text { Torremormojón } 5 \\
\text { Casasola } 2 \\
\text { Molina de A. } \\
\text { Nombrevilla } 1 \\
\text { Cendejas-2 } \\
\text { Ledanca } \\
\text { Nombrevilla } 10\end{array}$} & $\begin{array}{ll}\text { X } & \text { cf. } \\
\end{array}$ \\
\hline & & & & $\begin{array}{lll}X & x & x \\
x & x & x\end{array}$ \\
\hline & & & & $\begin{array}{lll}X & X & X \\
& y & y\end{array}$ \\
\hline & & & & $\frac{X \times X X}{X \times X X}$ \\
\hline & & & & $\frac{x \times x \times}{x \times x}$ \\
\hline & & & & $\mathrm{X} \times \mathbf{X}$ cf. \\
\hline \multirow{10}{*}{ 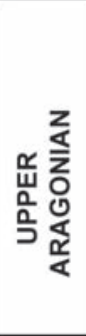 } & \multirow{5}{*}{$7 / 8$} & & & $\mathrm{XXX}$ \\
\hline & & \multirow{4}{*}{ G3 } & \multirow{5}{*}{\begin{tabular}{|l|} 
Escobosa \\
Cuesta del R.-1 \\
Cuesta del R.-3 \\
Parrilla \\
Lupiana \\
\end{tabular}} & $\mathrm{X} \times \mathrm{XX}$ \\
\hline & & & & $\mathrm{x} \times \mathrm{XX}$ \\
\hline & & & & cf. X \\
\hline & & & & $X \times X$ \\
\hline & \multirow{5}{*}{6} & \multirow{5}{*}{ G2 } & & $\begin{array}{lll}X & X & \text { ct. } X X \\
X X X & X X X\end{array}$ \\
\hline & & & \multirow{4}{*}{$\begin{array}{l}\text { Manchones } 1 \\
\text { Otero-2 } \\
\text { Duredos-1 } \\
\text { Simancas-2 } \\
\text { Paracuellos 3 } \\
\end{array}$} & $\mathrm{X} \quad \mathrm{X}$ \\
\hline & & & & $\mathrm{XX}$ \\
\hline & & & & $\mathrm{XX}$ \\
\hline & & & & $\mathbf{X}$ \\
\hline
\end{tabular}

Figure 5. Distribution of selected rodent taxa from the upper Aragonian and lower Vallesian localities: Simancas-2, Duredos-1, Otero-2, La Parrilla, Casasola 2, Torremormojón 5 (García Moreno, 1988), Escobosa de Calatañazor (Sesé, 1980), Los Valles de Fuentidueña (Sesé \& López Martínez, 1981) and Cuesta del Rey1/3 from the Duero Basin; Paracuellos 3 (Sesé et al., 1985; Alberdi et al., 1985), Lupiana, Ledanca, Cendejas-2 (Sesé et al., 1990) and Molina de Aragón (Lacomba, 1988) from the Tagus Basin; Manchones 1 (Daams \& Freudenthal, 1988), Nombrevilla 2 and Nombrevilla 1 (classical site) from the Calatayud- DarocaNombrevilla (Teruel and Zaragoza) Basin (Álvarez Sierra et al., 2003) .
The rodent assemblages from the upper Aragonian and the early Vallesian (zone $\mathrm{H}$ ) sites, generally display a great continuity in relation to most of the taxa, except for the last record of the genus Armantomys in the upper Aragonian (Sesé, 2006). Megacricetodon ibericus and Megacricetodon minor-Megacricetodon debruijni, two very characteristic taxa due to represent the stages of evolution of two different lineages of the genus Megacricetodon, are common in these assemblages and also are present in some sites of the Vallès-Penedès (Catalonia), (Agustí, 1982; Casanovas-Vilar et al., 2016), the second represented by Megacricetodon debruijni in the Vallesian. The interior basins of the Iberian Peninsula also present great continuity in the record of the other species of cricetids, glirids, and castorids between the Aragonian/Vallesian transition. The castorids, which were absent during the Ramblian, and lower and middle Aragonian, reappear at the end of the upper Aragonian, and they have since been recorded until the end of the Neogene (Sesé, 2006).

From the paleoenvironmental perspective, the genera Heteroxerus and Armantomys suggest a dry and open environment with savannahs and meadows, whereas Megacricetodon might have lived in different types of environments that could be dry and open with savannahs and meadows, or in moist and wooded ones (Weerd \& Daams, 1978; Daams et al., 1988). The genus Megacricetodon is the most abundant micromammal taxon in Cuesta del Rey-1, with an MNI of 20 of the total MNI of 25 (80\% of the total percentage of the MNI) (Fig. 6). In the rodent assemblages from the end of the Aragonian

\begin{tabular}{|c|c|c|}
\hline NMI - \% NMI & NMI & $\% \mathrm{NMI}$ \\
\hline cf. Miosorex sp. & 1 & 4 \\
\hline Heteroxerus sp. & 1 & 4 \\
\hline Armantomys cf.tricristatus & 1 & 4 \\
\hline Megacricetodon ibericus & 18 & 72 \\
\hline Megacricetodon minor - Megacricetodon debruijni & 2 & 8 \\
\hline Hispanomys sp. & 1 & 4 \\
\hline Democricetodon sp. & 1 & 4 \\
\hline TOTAL & 25 & 100 \\
\hline
\end{tabular}

a

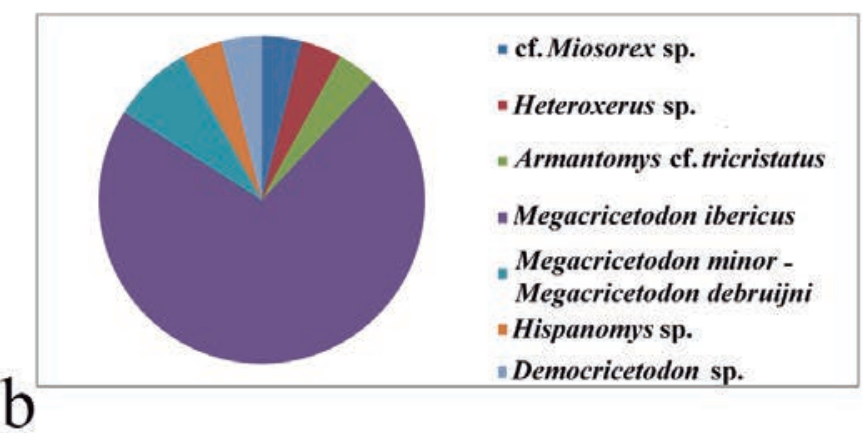

Figure 6. a) Abundance of micromammal taxa from Cuesta del Rey-1 according to the MNI, and to percentage of the MNI. b) Representation of the percentage abundance (\% of the MNI) of the micromammal taxa from Cuesta del Rey- 1 . 
in the central basins of the Iberian Peninsula, the genus Megacricetodon is also the most abundant taxon in general terms (Meulen \& Daams, 1992; Oliver Pérez, 2015). López Martínez et al. (2000) also highlight the great abundance of the genus Megacricetodon in the micromammal assemblages of the upper Aragonian in the central basins, which suggests an open savannah or steppe habitat, as it could happen in Cuesta del Rey-1 by the great abundance of Megacricetodon ibericus. With regard to climate, Meulen $\&$ Daams (1992) suggest that in the upper Aragonian there was a cooling event, with some oscillations of humidity. Additionally, the presence of Dorcatherium at Cuesta del Rey-3 suggests the existence in this area of permanent watercourses, which it is consistent with the sedimentary change observed in the Cuesta del Rey section. Moreover, independently from the relationship between the Villatoro facies, located at the base of Cuesta del Rey Butte, and the Riocerezo "Marls, clays and limestones" facies, the Cuesta del Rey terrigenous sediments represent alluvial environments prograding on the marsh/lacustrine sediments of the lower facies. The terrigenous sedimentation in this area ends with the deposition of marls and limestones (Pineda, 1997). This sequence is comparable in age and general characteristics with the Paramo Superior sequence described by Nozal \& Herrero (2005) on the SE border of the Duero Basin. It is testimony to a general change in the environment towards wetter conditions in the Iberian central basins (Calvo et al., 1993).

\section{CONCLUSIONS}

The study of the mammal fauna of the Cuesta del Rey sites represents an important contribution to a better understanding of the Neogene faunas and biostratigraphy of the Duero Basin. Unfortunately, despite the great palaeontological potential of this area, no other studies have been conducted since the prospection of Olmo et al. (2008). Moreover, the mammal assemblages of the Aragonian/Vallesian transit deserve particular attention in different basins: García Moreno (1988) and Álvarez Sierra et al. (1990b) in the Duero Basin; Álvarez Sierra et al. (2003) and Dam et al. (2014) in the area of DarocaNombrevilla; García-Paredes et al. (2016) in the area of Calatayud-Montalbán; and Casanovas-Vilar et al. (2016) in the Vallès-Penedès Basin (Catalonia). The rodent assemblage of Cuesta del Rey-1 confirms the fact that no significant change clearly marks the boundary between the late Aragonian (middle Miocene) and the early Vallesian (upper Miocene) in Iberian continental environments.

\section{ACKNOWLEDGMENTS}

We first wish to thank the editors for the invitation to participate in this tribute to Prof. Pascual Rivas. We wish also to thank the following people for their assistance: Eduardo Piles and Antonio Pineda (EPTISA), who offered to conduct the paleontology of the "Hoja del Magna" 1910 (200) of Burgos, containing the Cuesta del Rey-1 site, and to show us its location; Manuel Arce and Enrique Soto, who accompanied us in the prospection and helped us to recover the samples; $\mathrm{M}^{\mathrm{a}}$ Ángeles Álvarez Sierra, who provided us with the macromammal remains found by Nieves López in Cuesta del Rey-3; Laura Tormo from the Laboratorio de Microscopia Óptica (Optical Microscope Laboratory) of the MNCN, who took the photographs of the micromammal tooth. Thanks are due to Cormac de Brun for the manuscript revision, to the editor and the reviewers, Isaac Casanovas-Vilar and Antonio García-Alix, which suggestions contributed to improve the manuscript, and to Enrique Soto for his invaluable assistance in the graphic editing of the micromammal figures. Support from the Project CGL2015-68333-P (MINECO/FEDER, UE) and the Research Group BSCH-UCM 910607 is gratefully acknowledged.

\section{REFERENCES}

Agustí, J. 1978. Fahlbuschia crusafonti nov. sp., cricétido nuevo del Astaraciense superior del Vallés-Penedés. Bull. Inform. Inst. Pal. Sabadell, 10, 63-68.

Agustí, J. 1982. Biozonación del Neógeno continental de Cataluña mediante roedores (Mammalia). Acta Geologica Hispanica, 17, 21-26.

Alberdi, M.T., Hoyos, M., Mazo, A.V., Morales, J., Sesé, C. \& Soria, D. 1985. Biostratigrafía, paleoecología y biogeografía del Terciario de la provincia de Madrid. In: Geología y Paleontología del Terciario Continental de la Provincia de Madrid (coord. Alberdi, M.T.). CSIC, MNCN, 99-105.

Álvarez Sierra, M.A., Daams, R., Lacomba, J.I., López Martínez, N., Meulen, A.J. van der, Sesé, C. \& Visser, J. de. 1990a. Palaeontology and biostratigraphy (micromammals) of the continental Oligocene-Miocene deposits of the North-Central Ebro Basin (Huesca, Spain). Scripta Geologica, 94, 1-77.

Álvarez Sierra, M.A., Civis, J., Corrochano, A., Daams, R., Dabrio, C.J., García, E., González, A., López Martínez, N., Mediavilla, R., Rivas Carballo, R. \& Valle, M.F. 1990b. Un estratotipo del límite Aragoniense-Vallesiense (Mioceno Medio-Mioceno Superior) en la sección de Torremormojón (Cuenca del Duero, Provincia de Palencia). Actas de las IV Jornadas de Paleontología, Salamanca, 1988, Acta Salmaticensia, 68, 57-64.

Álvarez Sierra, M.A., Calvo, J.P., Morales, J., Alonso-Zarza, A., Azanza, B., García Paredes, I., Hernández Fernández, 
M., van der Meulen, A.J., Peláez-Campomanes, P., Quiralte, V., Salesa, M.J., Sánchez, I.M. \& Soria, D. 2003. El tránsito Aragoniense-Vallesiense en el área de Daroca-Nombrevilla (Zaragoza, España). Coloquios de Paleontología, Vol. Ext. 1, 25-33.

Antunes, M.T. \& Mein, P. 1981. Vertébrés du Miocène moyen de Amor (Leiria) importance stratigraphique. Ciências da Terra, 6, 169-188.

Badillo, L. 1952. Nota sobre un nuevo yacimiento de Mastodon longirostris (Kaup). Notas Comunicaciones del Instituto Geológico y Minero de España, 28, 3-6.

Baudelot, S. \& Collier, A. 1982. Les faunes de mammifères miocènes du Haut-Armagnac (Gers, France): Les Gliridés (Mammalia, Rodentia). Geobios, 15, 705-727; doi: 10.1016/S0016-6995(82)80003-X.

Bergounioux, F.M. \& Crouzel, F. 1958. Les mastodontes d'Espagne. Estudios Geológicos, 14, 224-345.

Bowdich, T. E. 1821. An analysis of the Natural Classifications of Mammalia: for the Use of Students and Travellers. Printed by J. Smith. Paris.

Bruijn, H. de. 1966. Some new Miocene Gliridae (Rodentia, Mammalia) from the Calatayud area (Prov. Zaragoza, Spain). I. Proc. Kon. Ned. Akad. v. Wetensch., Series B, 69, 1-21.

Bruijn, H. de. 1967. Gliridae, Sciuridae y Eomyidae (Rodentia, Mammalia) miocenos de Calatayud (provincia de Zaragoza, España) y su relación con la bioestratigrafía del área. Boletín del Instituto Geológico y Minero de España, LXXVIII, 4-187.

Calvo, J.P., Daams, R., Morales, J., López-Martínez, N., Agustí, J., Anadón, P., Armenteros, I., Cabrera, L., Civis, J., Corrochano, A., Díaz-Molina, M., Elizaga, E., Hoyos, M., Martín-Suárez, E., Martínez, J., Moissenet, E., Muñoz, A., Pérez-García, A., Pérez-González, A., Portero, J.M., Robles, F., Santisteban, C., Torres, T., Van der Meulen, A.J., Vera, J.A. \& Mein, P. 1993. Up-to-date Spanish continental Neogene synthesis and Paleoclimatic interpretation. Revista de la Sociedad Geológica de España, 6, 29-40.

Casanovas-Vilar, I., Garcés, M., van Dam, J., GarcíaParedes, I., Robles, J.M. \& Alba, D.M. 2016. An updated biostratigraphy for the late Aragonian and Vallesian of the Vallès Penedès (Catalonia). Geologica Acta, 14, 195-217; doi: 10.1344/GeologicaActa2016.14.3.1.

Crusafont, M., Villalta, J.F. de \& Truyols, J. 1955. El Burdigaliense continental del Vallés Penedés. Memorias y Comunicaciones del Instituto Geológico, 12, 3-272.

Cuenca Bescós, G. 1988. Revisión de los Sciuridae del Aragoniense y del Rambliense en la fosa de CalatayudMontalbán. Scripta Geologica, 87, 1-116.

Daams, R. 1990. Hypsodont Myomiminae (Gliridae, Rodentia) from the Miocene and the Oligocene-Miocene boundary interval of Spain. Scripta Geologica, 95, 1-62.

Daams, R. \& Freudenthal, M. 1988. Cricetidae (Rodentia) from the type-Aragonian: the genus Megacricetodon. In: Biostratigraphy and Paleoecology of the Neogene Micromammalian Faunas from the Calatayud-Teruel Basin (Spain) (ed. Freudenthal, M.). Scripta Geologica, Special Issue 1, 39-132.
Daams, R., Freudenthal, M. \& Meulen, A.J. van der. 1988. Ecostratigraphy of micromammal faunas from the Neogene of Spain. In: Biostratigraphy and Paleoecology of the Neogene Micromammalian Faunas from the Calatayud-Teruel Basin (Spain) (ed. Freudenthal, M.). Scripta Geologica, Special Issue 1, 287-302.

Dam, J. van, Krijgsman, W., Abels, H.A., Álvarez-Sierra, M.Á., García-Paredes, I., López-Guerrero, P., PeláezCampomanes, P. \& Ventra, D. 2014. Updated chronology for Middle to Late Miocene mammal sites of the Daroca area (Calatayud-Montalbán Basin, Spain). Geobios, 47, 325-334; doi: 10.1016/j.geobios.2014.07.002.

Fahlbusch, V. 1964. Die Cricetiden (Mammalia) der Oberen Süsswassermolasse Bayerns. Abh. Bayer. Akad. Wiss., 118, 1-136.

Fischer, G. 1814. Zoognosia Tabulis Synopticis Illustrata. Volumen Tertium. Quadrupedum Reliquorum. Cetorum et Montrymatum Descriptionem Continens. Nicolai Sergeidis Vsevolozky, Mosquae, 732 pp.

Fischer de Waldheim, G. 1817. Adversaria zoological fasciculus primus. Memoires de la Sociéte Impériale des Naturalistes de Moscou, 5, 357-428.

Forsyth Major, C.J. 1893. On some Miocene Squirrels, with remarks on the Dentition and Classification of the Sciurinae. Proceedings of the Zoological Society of London, 1893, 179-215.

Freudenthal, M. 1963. Entwicklungsstufen der miozänen Cricetodontinae (Mammalia, Rodentia) Mittelspaniens und ihre stratigraphische Bedeutung. Beaufortia, 119, 51-157.

Freudenthal, M. 1966. On the Mammalian fauna of the Hipparion-beds in the Calatayud-Teruel Basin (Prov. Zaragoza, Spain). Part I. The genera Cricetodon and Ruscinomys (Rodentia). Proc. Koninkl. Nederl. Akademie va Wetenschappen, Series B, 69, 296-317.

Freudenthal, M. 1968. On the Mammalian fauna of the Hipparion-beds in the Calatayud-Teruel Basin (Prov. Zaragoza, Spain). Part IV. The genus Megacricetodon (Rodentia). Proc. Koninkl. Nederl. Akademie va Wetenschappen, Series B, 71, 57-72.

Freudenthal, M. \& Daams, R. 1988. Cricetidae (Rodentia) from the type-Aragonian: the genera Democricetodon, Fahlbuschia, Pseudofahlbuschia nov. gen., and Renzimys. In: Biostratigraphy and Paleoecology of the Neogene Micromammalian Faunas from the Calatayud-Teruel Basin (Spain) (ed. Freudenthal, M.). Scripta Geologica, Special Issue 1, 133-252.

García Moreno, E. 1988. The Miocene rodent biostratigraphy of the Duero Basin (Spain): A proposition for a new Aragonian/Vallesian iimit. Paleontologia i Evolució, 22, 103-112.

García Paredes, I. 2006. Patrones evolutivos de los Gliridae (Rodentia, Mammalia) del Mioceno inferior y medio del área tipo del Aragoniense (Cuenca de CalatayudMontalbán). Tesis Doctoral, Universidad Complutense de Madrid (unpublished).

García-Paredes, I., Álvarez-Sierra, M.Á., Van den Hoek Ostende, L.W., Hernández-Ballarín, V., Hordijk, K., López-Guerrero, P., Oliver, A. \& Peláez-Campomanes, 
P. 2016. The Aragonian and Vallesian high-resolution micromammal succession from the Calatayud-Montalbán Basin (Aragón, Spain). Comptes Rendus Palevol; doi: 10.1016/j.crpv.2015.09.014.

Gray, J.E. 1821. On the natural arrangement of vertebrose animals. London Medical Repository, 15, 296-310.

Kaup, J.-J. \& Scholl, J.B. 1834. Verzeichniss der Gypsabgüsse vonden Ausgezeichnetsten Urweltlichen Thierresten des Grossherzoglichen Museums zu Darmstadt (2. Ausgabe). Darmstadt: Diehl, 6-28.

Kretzoi, M. 1959. New names for Soricid and Arvicolid homonyms. Vertebrata Hungarica, 1, 247-249.

Lacomba Andueza, J.I. 1988. Rodents and lagomorphs from a lower Vallesian fissure filling near Molina de Aragón (prov. Guadalajara, Spain). In: Biostratigraphy and Paleoecology of the Neogene Micromammalian Faunas from the Calatayud-Teruel Basin (Spain) (ed. Freudenthal, M.). Scripta Geological, Spec. Issue, 1, 19-38.

Lacomba, J.I. \& Martínez-Salanova, J. 1988. Quercomys bijmai gen. nov. sp. nov. (Gliridae, Rodentia, Mammalia) del tránsito Oligoceno-Mioceno español. Estudios Geológicos, 44, 107-118.

Lartet, E. 1851. Notice sur la Colline de Sansan, Suivie d'une Récapitulation des Diverses Espèces d'Animaux Vertébrés Fossiles, Trouvés soit à Sansan, soit dans d'Autres Gisements du Terrain Tertiaire du Miocène dans le Bassin Sous-Pyrénéen. J.-A. Portes, Auch, 1-47.

Linnaeus, C. 1758. Systema Naturce per Regna Tria Naturce, Secundum Classses, Ordines, Genera, Species, cum Characteribus, Differentiis, Synonymis, Locis. Editio decima reformata 1758, Holmiæ, Impensis direct. Laurentii Salvii (Salvius publ.). Estocolmo.

López Guerrero, P., Álvarez Sierra, M.A., López-Antoñanzas, R., Oliver Pérez, A. \& Peláez-Campomanes, P. 2008. Cricetodontini (Cricetidae, Rodentia) del Aragoniense superior (Mioceno medio) de Nombrevilla 2, (Zaragoza, España). In: Palaeontologica Nova (eds Esteve, J. \& Meléndez, G.). SEPAZ, 8: 259-27.

López Martínez, N., Sesé Benito, C. \& Sanz García, J.L. 1977. La Microfauna (Rodentia, Insectivora, Lagomorpha y Reptilia) de las fisuras del Mioceno medio de Escobosa de Calatañazor (Soria, España). Acta Geológica Hispánica, 12, 60-68.

López Martínez, N., Élez Villar, J., Hernando Hernando J.M., Luis Cavia, A., Mínguez Gandú, D., Polonio Martín, I., Salesa, M.J., Mazo, A.V. \& Sánchez, I.M. 2000. Los vertebrados fósiles de Somosaguas (Pozuelo de Alarcón, Madrid). In: Patrimonio Paleontológico de la Comunidad de Madrid (coord. Morales, J.). Arqueología, Paleontología y Etnografía, 6, 130- 140.

Mazo Pérez, A.V. 1977. Revisión de los Mastodontes de España. Tesis doctoral, Universidad Complutense de Madrid, 420 pp. (unpublished).

Mein, P. 1958. Les Mammifères de la Faune Sidérolithique de Vieux-Collonges. Nouv. Arch. Mus. Hist. Nat. Lyon, 5, 122 pp.

Mein, P. 1975. Résultats du groupe de travail des vertébrés. In: Report on Activity of the RCMNS Working Groups (1971-1975) (ed. Senes, J.). Bratislava, 78-81.
Mein, P. \& Freudenthal, M. 1971. Une nouvelle classification des Cricetidae (Mammalia, Rodentia) du Tertiaire de l'Europe. Scripta Geologica, 2, 1-37.

Meulen, A.J. van der \& Daams, R. 1992. Evolution of Early-Middle Miocene rodent faunas in relation to longterm palaeoenvironmental changes. Palaeogeography, Palaeoclimatology, Palaeoecology, 93, 227-253; doi: 10.1016/0031-0182(92)90099-Q.

Meulen, A.J. van der, Peláez-Campomanes, P. \& Daams, R. 2003. Revision of medium-sized Cricetidae from the Miocene of the Daroca-Villafeliche area in the Calatayud-Teruel basin (Zaragoza, Spain). Coloquios de Paleontología, Vol. Ext. 1, 385-441.

Meyer, H. von. 1846. Mitteilungen an Prof. Bronn gerichtet. Neues Jahrbuch für Mineralogie, Geologie und Paläontologie, 1846, 462-476.

Milne Edwards, A. 1864 . Recherches anatomiques, zoologiques et paléontologiques sur la famille des chevrotains. Annales des Sciences naturelles, 5e série, Zoologie 2, 1-132.

Morales, J. \& Sesé, C. 1997. Información complementaria. Paleontología (Vertebrados). MAGNA Hojas $N^{o}$ 166-Villadiego, $N^{o}$ 198-Osorno, $N^{o}$ 199-Sasamón, $N^{o}$ 200-Burgos. IGME.

Morales, J., Sánchez I.M. \& Quiralte V. 2012. Les Tragulidae (Artiodactyla) de Sansan. In: Mammifères de Sansan. (eds Peigné, S. \& Sen, S.). Mémoires du Muséum national d'Histoire Naturelle, 203, 225-247.

Muirhead, L. 1819. Mazology. The Edinburgh Encyclopedia, $13,393-486$.

Nozal, F. \& Herrero, A. 2005. El Mioceno del borde meridional del corredor Aranda del Duero-Burgo de Osma (SE Cuenca del Duero). Revista de la Sociedad Geológica de España, 18, 21-37.

Oliver Pérez, A. 2015. Evolution of Megacricetodon from the Aragonian and Vallesian (Miocene) of the Iberian Peninsula. Tesis Doctoral, Universidad Complutense de Madrid (unpublished).

Olmo, A. del, López-Martínez, N. \& Baltuille, J.M. 2008. Importancia de las dataciones con micromamíferos en la minería de Rocas y Minerales Industriales (Depósitos neógenos del NE de la provincia de Burgos, España. GeoTemas, 10, 1535-1538.

Owen, R. 1848. On the Archetype and Homologies of the Vertebrate Skeleton. London: van Voorst. 203 pp.

Pickford, M. \& Morales, J. 2003. New Listriodontinae (Suidae, Mammalia) from Europe and a review of listriodont evolution, biostratigraphy and biogeography. Geodiversitas, 25, 1-58.

Pineda, A. 1997. Mapa Geológico del España escala 1: 50,000, $2^{a}$ Serie (MAGNA). Hoja de Burgos, 200 (19-10). Instituto Geológico y Minero de España. Servicio de Publicaciones Ministerio de Industria. Madrid, Spain.

Reumer, J.W.F. 1984. Ruscinian and early Pleistocene Soricidae (Insectivora, Mamalia) from Tegelen (The Netherlands) and Hungary. Scripta Geologica, 73, 1-173.

Schaub, S. von. 1944. Cricetodontiden der Spanischen Halbinsel. Bericht der Schwizerischen Paläontologischen Gesellschaft Eclogae Geologicae Helvetiae, 37, 453-457. 
Sesé, C. 1977. Los cricétidos (Rodentia, Mammalia) de las fisuras del Mioceno Medio de Escobosa de Calatañazor (Soria, España). Trabajos sobre Neógeno-Cuaternario, 8, 27-180.

Sesé, C. 1980. Mamíferos del Mioceno Medio de Escobosa de Calatañazor (Soria). Tesis Doctoral, Universidad Complutense de Madrid (unpublished), $388 \mathrm{pp}$.

Sesé, C. 1988. Distribución de los roedores (Mammalia) en España durante el Neógeno. Paleontologia i Evolució, $22,55-60$.

Sesé, C. 2006. Los roedores y lagomorfos del Neógeno de España. Estudios Geológicos, 62, 429-480.

Sesé, C. \& López Martínez, N. 1981. Los micromamíferos (Insectivora, Rodentia y Lagomorpha) del Vallesiense Inferior de Los Valles de Fuentidueña (Segovia, España). In: Geología y Paleontología del Yacimiento Neógeno de Los Valles de Fuentidueña, Segovia (España) (coord. Alberdi, M.T.). Estudios Geológicos, 37, 369-381.
Sesé, C., López Martínez, N. \& Herráez, E. 1985. Micromamíferos (Insectívoros, roedores y Lagomorfos) de la provincia de Madrid. In: Geología y Paleontología del Terciario Continental de la provincia de Madrid. (coord. Alberdi, M.T.). CSIC, MNCN, 29-39.

Sesé, C., Alonso Zarza, A.M. \& Calvo, J.P. 1990. Nuevas faunas de micromamíferos del Terciario continental del NE de la Cuenca de Madrid (Prov. de Guadalajara, España). Estudios Geológicos, 46, 433-451.

Stehlin, H.G. \& Schaub, S. 1951. Die trigonodontie der Simplicidentaten Nager. Schweizerische Paläontologische Abhandlungen, 67, 1-384.

Waddell, P.J., Okada, N. \& Hasegawa, M. 1999. Towards resolving the interordinal relationships of placental mammals. Systematic Biology, 48, 1-5.

Weerd, A. Van de \& Daams, R. 1978. Quantitative composition of rodent faunas in the Spanish Neogene and paleoecological implications. Proc. Kon. Ned. Akad. Wetens., B, 81, 448-473. 
